ELORE (ISSN 1456-3010), vol. 17 - 2/2010.

Julkaisija: Suomen Kansantietouden Tutkijain Seura ry.

[http://www.elore.fi/arkisto/2_10/palmgren2_2_10.pdf]

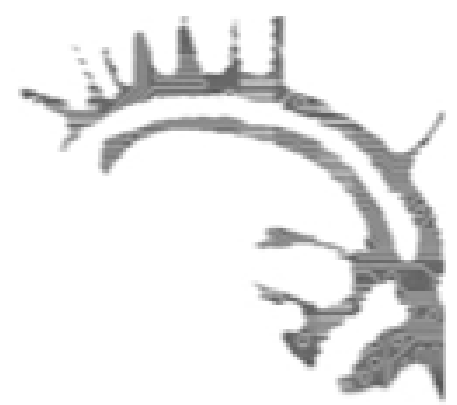

ReCEnsion

\title{
INTERNETS KULTURHISTORIA I ETT FINLÄNDSKT PERSPEKTIV
}

SAARIKOSKI, PETRI \& SUOMINEN, JAAKKO \& TURTIAINEN, RIIKKA \& ÖSTMAN, SARI 2009: Funetista Facebookiin. Internetin kulttuuribistoria. Helsinki: Gaudeamus. 332 sidor.

$\underline{\text { Ann-Charlotte Palmgren }}$

Som bokens titel nämner är syftet med boken att redovisa för Internets kulturhistoria, en gedigen målsättning, som kräver avgränsningar. Författarna till boken, samtliga verksamma som forskare vid ämnet digital kultur vid Åbo Universitet, har valt att koncentrera sig främst på ett finländskt perspektiv. Ett mycket välkommet perspektiv som, vad jag känner till, inte tidigare behandlats i ett samlingsverk, vilket man kan se denna bok som. Rubriken hänvisar även till Funet och Facebook, vilket innebär att tidsperspektivet i boken avgränsas, med några undantag, till början av 1980-talet tills idag. Funet är en förkortning på Finnish University and Research Network, vilket grundades av undervisningsministeriet år 1984. Funet är ett avancerat nätverk ämnat för datakommunikation och tillhandahåller idag åtkomst till Internet för ungefär 80 stycken forskningsorganisationer och ungefär 350000 användare. Facebook grundades i sin tur av Mark Zuckerberg och kan beskrivas som ett socialt nätverk, som blev ytterst populärt i Finland år sommaren 2007. Sommaren 2009 hade Facebook över 200 miljoner användare, världen över. 
Ann-Charlotte Palmgren: Internets kulturhistoria i ett finländskt perspektiv

\section{FRÅN INFORMATION TILL SPEL}

Antologin har många intressanta kapitel, som täcker flera olika aspekter av kulturella dimensioner av Internet. Boken börjar med Petri Saarikoskis artikel om användargrupper och erfarenheter av datornätverksförsök från 1960-talet till början av 1990-talet, särskilt fokus i detta kapitel ligger på BBS, det vill säga Bulletin Board System. Med Bulletin Board System menas datorer på 1980- och 1990-talet som förenades via modem och telefonlinjen. Användargrupperna som här beskrivs kan $i$ ett finländskt perspektiv ses som pionjärerna och de första entusiasterna som sysslade med datorer på sin fritid. Saarikoski fortsätter i det andra kapitlet med visioner relaterade till datanätverk och i relation till tanken om televisionen som central kommunikationsmedel på 1970-talet. I det följande kapitlet av boken skriver Jaakko Suominen om Internet som ett informationslager, verktyg samt som en förändring av kunskap och information kring Internet. Suominen visar att ordet Internet första gången användes i en artikel i Helsingin Sanomat år 1993 och förekomsten ökade explosionsartat fram till 2000 då förekomsten dalade en aning tills det senare blev mera stabilt, med cirka 1500 omnämnanden per år. När det gäller Internet som ett informationslager beskriver Suominen hur användandet av sökmotorer växt och hur information och kunskap nu också kan ses som socialt, till exempel i och med Wikipedia. Wikipedia kan ses som ett uppslagsverk på nätet där vem som helst kan lägga till text, ta bort text och omformulera.

Sari Östman skriver i sin tur om Internet i relation till tiden, genom att studera tiden på olika sätt. Bland annat hävdar Östman att Internet har fungerat som en symbol av vår tid, samtidigt som man anser att Internet har förändrat användarnas livsrytm. I kapitlet skrivet av Riikka Turtiainen behandlas känslor relaterade till Internet, och särskilt när det gäller olika sociala medier och internetdejting. Jag skulle kategorisera Turtiainens artikel som mera beskrivande än diskuterande och analyserande, vilket också kan sägas om de övriga artiklarna. Turtiainen beskriver till exempel mycket noggrant vad en portal är, och när hon beskriver nätdejting är perspektivet historiskt och inleds med att beskriva de första formerna av nätdejting, då enkäter fylldes i och användes för att föra samman människor. Perspektivet är också historiskt och deskriptivt när tävlingen Miss Internet behandlas.

Det nästsista kapitlet i boken är skrivet av samtliga av bokens författare. Detta kapitel behandlar olika former av spel och lek på nätet. Även om artikeln behandlar lek är artikeln inte särskilt teoretisk. Lek får här särskilt representeras i beskrivningen av Facebook och där i formen av lekfullhet. Samtidigt kan boken inte kritiseras för ett oteoretiskt grepp, litteraturhänvisningarna är många och de för ofta till teoretiska och analyserande texter och studier. Boken avslutas av Jaakko Suominen som diskuterar Internet i relation till den finländska kulturen och samhället. Som sammanfattning konstaterar bokens författare att Internet är mångsidigt och föränderligt, samtidigt som det är både allmänt och partikulärt. 
Ann-Charlotte Palmgren: Internets kulturhistoria i ett finländskt perspektiv

\section{BOKENS MATERIAL OCH BOKEN SOM MATERIAL}

Materialet som bokens författare utgår från är ytterst imponerande och brett. Författarna utgår från artiklar från dagstidningar, magasin och nättidningar, televisionsprogram, intervjuer som utförts mellan år 2001 och 2009, minnesmaterial skrivet av studenter som studerar digital kultur vid universitet och studeranden vid ett seniorseminarium vid sommaruniversitet, ett flertal internetguider från 1992 och 2007, skönlitteratur, nätsidor, föreläsningar, rapporter, reklamblad och vetenskaplig litteratur.

Som bokens namn antyder ter sig målet med boken vara att redogöra för Internets kulturhistoria i ett finländskt perspektiv, det gör boken också. Samtidigt upplever jag personligen att jag gärna hade läst mera om det kulturella och att författarna kunde ha gett mindre rum till Internet som en teknologi. De enskilda kapitlen är mycket bra och kan gott läsas som fristående delar, men samtidigt saknade jag något. Sällan säger man att man saknade yta istället för befintligt djup, men det gjorde jag till en del när det gäller denna bok. Skulle gärna ha läst kortare kapitel och att författarna därmed fått med flera olika aspekter, till exempel näthandel och diskussioner om kroppslighet i relation till Internet. Samtidigt är boken ytterst välkommen som den är. Vad jag känner till har det inte tidigare skrivit en bok med detta mål och en klar plats, eller lucka finns för den att fylla. Boken innehåller relevanta litteraturhänvisningar, som för den intresserade läsaren vidare. Dessutom är boken rik på bilder för att personer som till exempel inte sedan förr är bekanta med datorspelet Doom ska få en bild av det, en imponerande förteckning över ord relaterade till Internet och korta men kraftfulla förklaringar av dessa, samt en kronologisk lista över det finländska datanätverkets framväxt, med start från år 1960-talet. Inte endast bokens artiklar kan upplevas som beskrivande och med ett historiskt perspektiv, även allt annat material som finns i boken fyller denna funktion.

Boken kan mycket väl rekommenderas för personer som allmänt är intresserade av fenomenet Internet i ett historiskt perspektiv och av studenter som studerar Internet från ett kulturvetenskapligt perspektiv. Humoristiskt avslutas det sista kapitlet med "Mitä netti on, sano sinä. Tai kato ***** Googlesta", vilket mycket väl sammanfattar boken. Den kritik som kan riktas mot boken bygger på att nätet är så mångfascetterat och föränderligt. En bok kan inte sammanfatta hela Internet och kan inte heller ta med alla aspekter. Detta tycks heller inte vara målet. Boken kan däremot mycket väl fungera som ett uppslagsverk för etnologer och folklorister intresserade av Internet.

Filosofie magister Ann-Charlotte Palmgren är doktorand i kvinnovetenskap vid Åbo Akademi. 